\title{
THE RIVER VALLEYS AS BIODIVERSITY RESERVOIRS FOR LAND SNAILS IN HIGHLY ANTHROPIC AREAS - THE CASE OF CISNĂDIE RIVER (ROMANIA)
}

\author{
Voichiţa GHEOCA * \\ * "Lucian Blaga” University of Sibiu, Faculty of Sciences, Department of Ecology and Environment \\ Protection, Dr. I. Rațiu Street, 5-7, Sibiu, Sibiu County, Romania, RO-550012, vgheoca@yahoo.com
}

DOI: 10.1515/trser-2015-0094

KEYWORDS: land snails, biodiversity, conservation, anthropic impact.

\begin{abstract}
This study focuses on the snail fauna of a river valley passing through two closely located settlements. Thirty six species of terrestrial gastropods were identified. Species such as Macrogastra borealis, Alinda fallax, Alinda viridana, Bulgarica vetusta, Monachoides vicinus, Drobacia banatica, are present along the river and abundant in the sampling stations downstream of Cisnădie town. The high specific diversity and the presence of typical forest species demonstrate the presence of fragments of habitat that can preserve populations of terrestrial gastropods, underlining the importance of river valleys in conservation and dispersion of these species.

RÉSUMÉ: Les vallées fluviales réservoirs de la biodiversité pour les gastéropodes terrestres dans les régions fortes anthropisés - étude de cas le Rivière Cisnădie (Roumanie).

L'étude est axée sur la faune de gastéropodes terrestres de la zone riveraine d'une rivière qui traverse deux établissements sur une distance relativement courte. 36 espèces de gastéropodes terrestres ont été identifiées. Des espèces telles que Macrogastra borealis, Alinda fallax, Alinda viridana, Bulgarica vetusta, Monachoides vicinus, Drobacia banatica sont présents le long de la vallée et abondantes en aval de Cisnădie. Une grande diversité spécifique et la présence d'espèces caractéristiques des habitats forestières, démontrent l'existence des fragments d'habitat qui peuvent conserver les populations de gastéropodes terrestres, soulignant l'importance des vallées fluviales pour la conservation et la dispersion de ces espèces.

REZUMAT: Văile râurilor rezervoare de biodiversitate pentru gastropodele terestre în zone puternic antropizate - studiu de caz Râul Cisnădie (România).

Studiul se concentrează pe fauna de gastropode terestre din zona ripariană a unui râu care traversează două așezări umane pe o distanță relativ scurtă. Un număr de 36 de specii de gastropode terestre au fost identificate. Specii precum Macrogastra borealis, Alinda fallax, Alinda viridana, Bulgarica vetusta, Monachoides vicinus, Drobacia banatica, sunt prezente de-a lungul văii și abundente în aval de orașul Cisnădie. Diversitatea specifică ridicată şi prezența speciilor caracteristice habitatelor forestiere demonstrează existența fragmentelor de habitat care pot conserva populațiile de gastropode terestre, subliniind importanța văilor râurilor pentru conservarea și dispersia acestor specii.
\end{abstract}




\section{INTRODUCTION}

Habitat destruction and fragmentation are among the major threats that affect land snail communities especially in highly anthropic areas, where urbanization, the development of industry and agriculture strongly affect the natural habitats (McKinney, 2002, 2008; Stoll et al., 2009; Douglas et al., 2013). Urbanization impact on land snails has been studied on some European countries (Horsák et al., 2009, 2013; Dedov and Penev, 2000; Gheoca, 2012), but the anthropogenic impact extends beyond the boundaries of the urban system as the human activities or their results are still present in the surrounding areas.

In Southern Transylvania the plateau area landscape is dominated by cultivated lands that, along with the development of urban and rural human settlements, industrial areas and associated infrastructure, are shaping the natural landscape transforming it into a predominantly anthropogenic one. In this landscape few natural habitats remain, especially in the vicinity of the urban areas, where most of the forests were cut down. The closest habitats to their natural state are the river valleys.

The Cisnădie River is one of the tributaries of Cibin River. The source of the river is in the Cibin Mountains, it is $18 \mathrm{~km}$ long and after a short course through a deciduous forest, passes through the central areas of a rural (Cisnădioara) and an urban (Cisnădie) settlement. The river is mostly natural in its forest sector, upstream of Cisnădioara, and starts to degrade before entering the village due to deforestation, grazing and tourism. The river banks have been strongly modified and regularized inside both localities. Downstream of Cisnădie, only patches of the former riverine forest remain, with most of the area under construction, including a part in the vicinity of a forest patch.

The aim of the study is to assess the land snail diversity along the river and the impact of anthropogenic modifications on this group as well as on the ability of the river valley to preserve significant snail populations.

\section{MATERIAL AND METHODS}

A visual search was used in 11 sampling stations along Cisnădie River valley (Fig. 1).

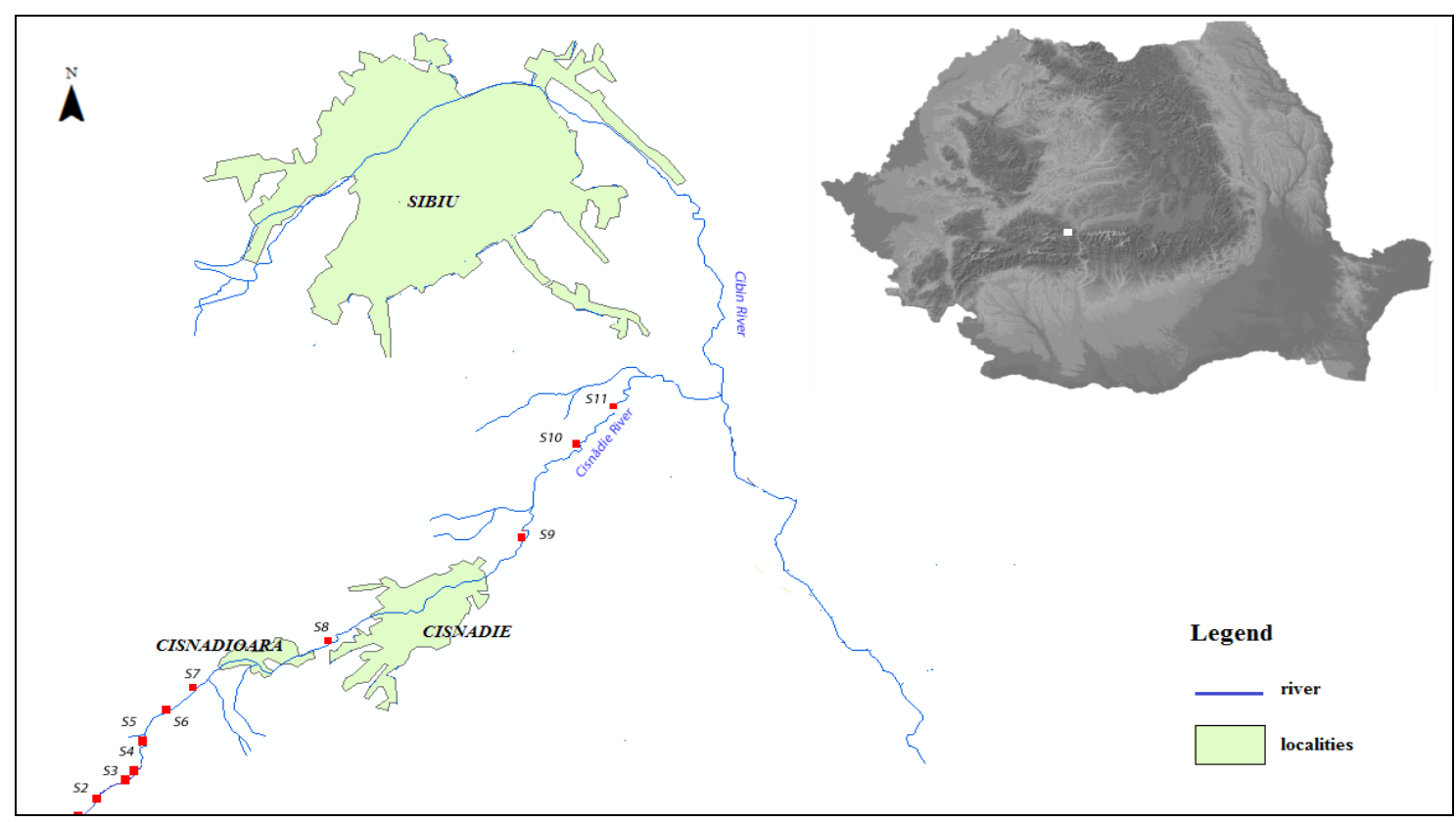

Figure 1: The location of sampling points. 
Seven sampling points were located upstream of Cisnădioara $(\mathrm{km} 2 ; 3 ; 3.7 ; 4.5 ; 5$; 6; 7), one between Cisnădioara and Cisnădie ( $\mathrm{km} \mathrm{8.8)}$ and three downstream of Cisnădie town $(\mathrm{km} \mathrm{13.3;} \mathrm{15;} \mathrm{16.2).} \mathrm{The} \mathrm{sampling} \mathrm{was} \mathrm{conducted} \mathrm{in} \mathrm{the} \mathrm{river} \mathrm{valley,} \mathrm{near} \mathrm{the} \mathrm{water}$ (Fig. 2). Snails were collected by hand, by two collectors during one hour in each sampling site, and an additional leaf litter sample was taken. About $20 \mathrm{l}$ of leaf litter were sieved and the material was sorted and identified in the laboratory (Pokryszko and Cameron, 1995). The key-book of Grossu (1981, 1983, 1987) and Welter-Schultes (2012) were used for species identification. The taxonomic list follows the Fauna Europaea (Bank, 2013). Species relative abundance and the Margalef diversity index were calculated and used to assess the land snail communities. The relative abundance was also used to build the affinity diagram of the sampling stations (single linkage method, Euclidean distance).

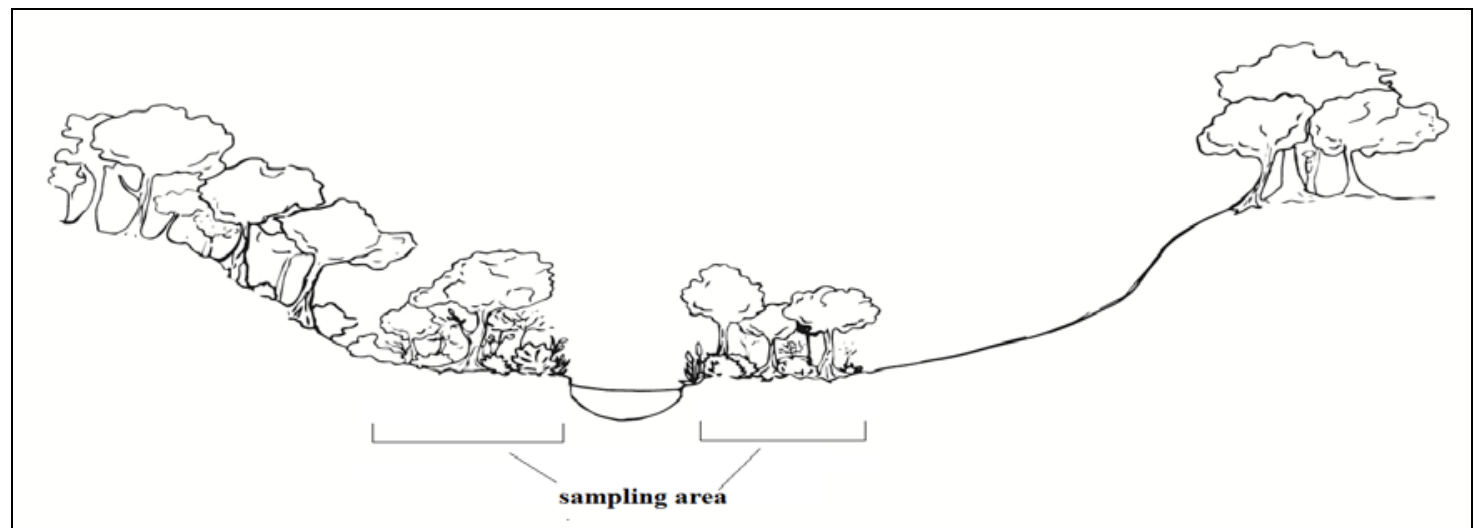

Figure 2: General cross-section of the valley, showing the location of the sampling area.

\section{RESULTS AND DISCUSSION}

Thirty six land snail species were identified in the area. The systematic list is presented in table 1 . The 11 sampling points were located in the forest area, upstream of Cisnădioara, S1-S7, between Cisnădioara and Cisnădie S8 and downstream of Cisnădie S9-S11. The number of species ranges between seven, for the most degraded sampling point (S6) and 20 at the last station downstream of Cisnădie (S11). Table 2 presents the number of individuals, species and the Margalef diversity index for each sampling station.

For the entire area, the most common species are Helix pomatia (highest frequency and relative abundance), and Vestia elata. In the forest area, upstream of Cisnădioara the most abundant species are Perforatella dibotrion, Monachoides vicinus, Discus perspectivus, Drobacia banatica, Vestia elata and Helix pomatia (Fig. 3). The first three species, along with other less abundant species such as Isognomostoma isognomostomos, Morlina depressa, Vitrea contracta, Vitrea transsylvanica and Alinda viridana, were found exclusively in the sampling stations upstream of the first locality.

Generally, their abundance decreases as the village is approached, with a high diversity (Margalef Index value) at sampling stations S1, S2 and S4 (Tab. 2). The sampling stations located near the localities have the lowest diversity values. The most degraded habitat was found in S6, an area with intensive pastoral activities, like sheep grazing and watering, located in the vicinity of a camping site. In this sector, the most abundant species are Helix pomatia, Vestia elata, Euomphalia strigella and Bulgarica vetusta. 
Table 1: The systematic list of land snail species found along the Cisnădie River valley (number of individuals, frequency (F\%), relative abundance (A\%) and the sampling points where each species was found).

\begin{tabular}{|c|c|c|c|c|}
\hline Species & Ind. & $\mathbf{F \%}$ & $\mathbf{A \%}$ & Sampling stations \\
\hline \multicolumn{5}{|l|}{ Carychiidae } \\
\hline Carychium (Carychium) minimum Müller O. F. 1774 & 2 & 18.18 & 0.12 & S2, S3 \\
\hline \multicolumn{5}{|r|}{ Succineidae } \\
\hline Succinea putris (Linnaeus, 1758) & 13 & 36.36 & 0.81 & S2, S9, S10, S11 \\
\hline \multicolumn{5}{|r|}{ Cochlicopidae } \\
\hline Cochlicopa lubrica (Müller O. F., 1774) & 10 & 36.36 & 0.62 & S2, S3, S7, S11 \\
\hline \multicolumn{5}{|l|}{ Orculidae } \\
\hline Sphyradium doliolum (Bruguière, 1792) & 3 & 9.09 & 0.19 & S5 \\
\hline \multicolumn{5}{|l|}{ Valloniidae } \\
\hline Vallonia pulchella (Müller O. F., 1774) & 1 & 9.09 & 0.06 & S10 \\
\hline Acanthinula aculeata (Müller O. F., 1774) & 1 & 9.09 & 0.06 & S4 \\
\hline \multicolumn{5}{|l|}{ Enidae } \\
\hline Merdigera obscura (Müller O. F., 1774) & 2 & 9.09 & 0.12 & S10 \\
\hline Chondrula tridens (Müller O. F., 1774) & 3 & 18.18 & 0.19 & S10, S11 \\
\hline \multicolumn{5}{|l|}{ Clausiliidae } \\
\hline $\begin{array}{r}\text { Cochlodina (Cochlodina) laminata } \\
\text { (Montagu, 1803) }\end{array}$ & 46 & 63.63 & 2.86 & $\begin{array}{l}\text { S1, S2, S3, S4, S8, } \\
\text { S10, S11 }\end{array}$ \\
\hline $\begin{array}{r}\text { Macrogastra (Pyrostoma) borealis } \\
\text { (Boettger O., 1878) }\end{array}$ & 52 & 18.18 & 3.23 & S10, S11 \\
\hline $\begin{array}{r}\text { Clausilia (Andraea) dubia } \\
\text { Draparnaud, } 1805\end{array}$ & 18 & 4.45 & 1.12 & S5, S7, S8, S10, S11 \\
\hline $\begin{array}{r}\text { Alinda (Pseudalinda) fallax } \\
\text { (Rossmässler, 1836) }\end{array}$ & 96 & 72.72 & 5.97 & $\begin{array}{l}\text { S2, S3, S4, S5, S6, } \\
\text { S7, S10, S11 }\end{array}$ \\
\hline $\begin{array}{r}\text { Alinda (Pseudalinda) viridana } \\
\text { (Rossmässler, 1836) }\end{array}$ & 11 & 27.27 & 0.68 & S1, S2, S5 \\
\hline $\begin{array}{r}\text { Vestia (Vestia) gulo } \\
\text { (Bielz E. A., 1859) }\end{array}$ & 31 & 45.45 & 1.93 & S1, S2, S4, S5, S11 \\
\hline $\begin{array}{l}\text { Vestia (Vestia) elata } \\
\text { (Rossmassler, 1836) }\end{array}$ & 217 & 72.72 & 13.49 & $\begin{array}{l}\text { S4, S5, S6, S7, S8, } \\
\text { S9, S10, S11 }\end{array}$ \\
\hline $\begin{array}{r}\text { Bulgarica (Strigilecula) vetusta } \\
\text { (Rossmässler, 1836) }\end{array}$ & 127 & 8.81 & 7.89 & $\begin{array}{l}\text { S1, S3, S4, S5, S6, } \\
\text { S7, S8, S10, S11 }\end{array}$ \\
\hline \multicolumn{5}{|l|}{ Patulidae } \\
\hline $\begin{array}{r}\text { Discus perspectivus } \\
\text { (Megerle von Mühlfeld, 1816) }\end{array}$ & 66 & 4.45 & 4.10 & S1, S2, S4, S5, S7 \\
\hline \multicolumn{5}{|l|}{ Pristilomatidae } \\
\hline Vitrea transsylvanica (Clessin, 1877) & 12 & 36.36 & 0.75 & S1, S2, S3, S4 \\
\hline Vitrea contracta (Westerlund, 1871) & 20 & 2.27 & 1.24 & S1, S2, S3 \\
\hline \multicolumn{5}{|l|}{ Oxychilidae } \\
\hline Oxychilus (Oxychilus) draparnaudi (Beck, 1837) & 18 & 27.27 & 1.12 & S9, S10, S11 \\
\hline Mediterranea depressa (Sterki, 1880) & 12 & 36.36 & 0.75 & S1, S2, S4, S5, S7 \\
\hline Aegopinella epipedostoma (Fagot, 1879) & 69 & 63.63 & 4.29 & $\begin{array}{l}\text { S1, S2, S4, S5, S9, } \\
\text { S10, S11 }\end{array}$ \\
\hline Aegopinella pura (Alder, 1830) & 10 & 36.36 & 0.62 & S1, S2, S3, S4, S5 \\
\hline Nesovitrea (Perpolita) hammonis (Strøm, 1765) & 2 & 9.09 & 0.12 & S3 \\
\hline \multicolumn{5}{|l|}{ Vitrinidae } \\
\hline Vitrina pellucida (Müller O. F., 1774) & 3 & 27.27 & 0.19 & S1, S2, S3 \\
\hline
\end{tabular}


Table 1 (continued): The systematic list of land snail species found along the Cisnădie River valley (number of individuals, frequency (F\%), relative abundance $(\mathrm{A} \%)$ and the sampling points where each species was found).

\begin{tabular}{|c|c|c|c|c|c|}
\hline Bradybaenidae \\
\hline Fruticicola fruticum (Müller O. F., 1774) & 108 & 54.54 & 6.71 & $\begin{array}{c}\text { S4, S5, S7, S8, S10, } \\
\text { S11 }\end{array}$ \\
\hline Hygromiidae & & 110 & 4.45 & 6.84 & S6, S8, S9, S10, S11 \\
\hline Euomphalia strigella (Draparnaud, 1801) & 110 & 18.18 & 0.25 & S9, S11 \\
\hline Pseudotrichia rubiginosa (Rossmässler, 1838) & 4 & 72.72 & 3.60 & $\begin{array}{c}\text { S1, S2, S3, S4, S5, } \\
\text { S6, S7, S8 }\end{array}$ \\
\hline Monachoides vicinus (Rossmässler, 1842) & 58 & 72.72 & S1, S2, S7 \\
\hline Perforatella dibothrion (Kimakowicz M., 1884) & 12 & 2.27 & 0.75 & \\
\hline Helicidae (Rrobacia banatica (Rossmässler, 1838) & 64 & 9.91 & 3.98 & $\begin{array}{c}\text { S1, S2, S3, S4, S6, } \\
\text { S7, S8, S9, S10, S11 }\end{array}$ \\
\hline Faustina faustina (Rossmässler, 1835) & 18 & 27.27 & 1.12 & S2, S3, S7 \\
\hline Isognomostoma isognomostomos (Schröter, 1784) & 5 & 27.27 & 0.31 & S1, S3, S4 \\
\hline Cepaea (Austrotachea) vindobonensis & 11 & 3.36 & 0.68 & S8, S9, S10, S11 \\
(Pfeiffer C., 1828) & 11 & 353 & 100 & 21.94 & $\begin{array}{c}\text { S1, S2, S3, S4, S5, S7, S8, S9, S10, } \\
\text { S11 }\end{array}$ \\
\hline Helix (Helix) pomatia Linnaeus, 1758 & 353 & & & S9, S10, S11 \\
\hline Helix (Helix) lutescens Rossmässler, 1837 & 21 & 27.27 & 1.31 &
\end{tabular}

Table 2: Number of individuals, species and the value of Margalef diversity index in each sampling station.

\begin{tabular}{|c|c|c|c|}
\hline $\begin{array}{c}\text { Sampling } \\
\text { station }\end{array}$ & $\begin{array}{c}\text { Nomber } \\
\text { of specimens }\end{array}$ & $\begin{array}{c}\text { Nomber } \\
\text { of species }\end{array}$ & $\begin{array}{c}\text { Margalef } \\
\text { Index }\end{array}$ \\
\hline S1 & 90 & 16 & 12.46 \\
\hline S2 & 94 & 19 & 9.12 \\
\hline S3 & 86 & 15 & 6.62 \\
\hline S4 & 91 & 16 & 7.66 \\
\hline S5 & 146 & 14 & 5.54 \\
\hline S6 & 60 & 7 & 3.37 \\
\hline S8 & 198 & 13 & 5.27 \\
\hline S9 & 167 & 9 & 3.60 \\
\hline S10 & 113 & 10 & 4.38 \\
\hline S11 & 248 & 18 & 7.10 \\
\hline
\end{tabular}

The two sampling stations located more than two km from Cisnădie, have a totally different land snail community, dominated by Fruticicola fruticum, Alinda fallax, Aegopinella epipedostoma, Macrogastra borealis and Vestia elata. Despite the high values in species number (18 and 20 respectively), the specific diversity remains below the values registered in the upstream sector. 
The dendrogram built of species abundance (Fig. 4) shows the similarity between the sampling stations located upstream (S2, S3, S1, and S4). A second cluster is formed by S5 and S7, still upstream but closer to the first locality. The rest of the sampling stations from the proximity of localities do not form a group or discriminate from each other, but are close to the upstream stations, while the last two sampling points are totally distinctive as the land snail communities in these stations are largely different from the rest.

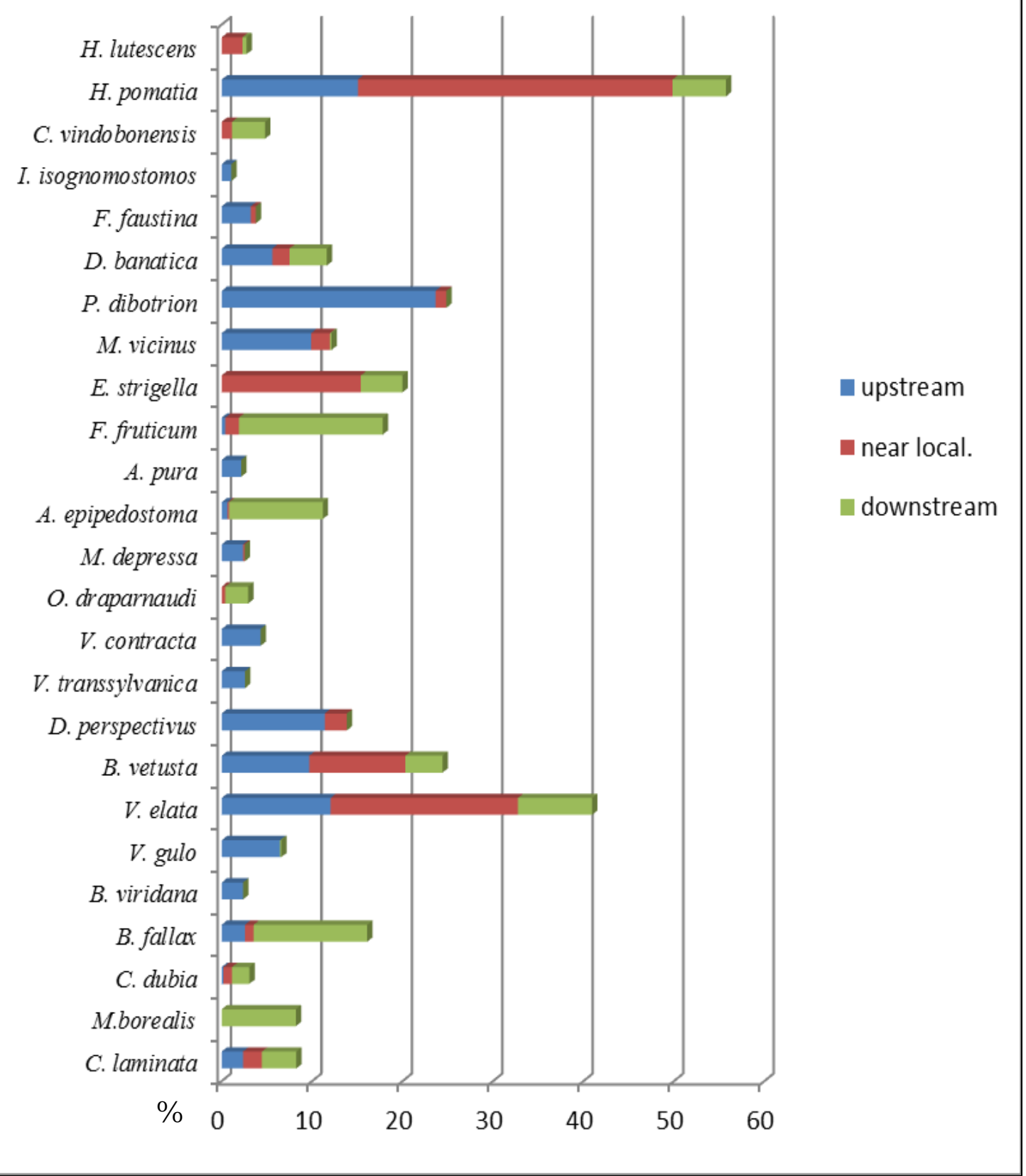

Figure 3: The relative abundance of the most common land snail species in the sampling stations split in three categories S1-S5, upstream; S6-S9, near localities; S10-S11, downstream. 


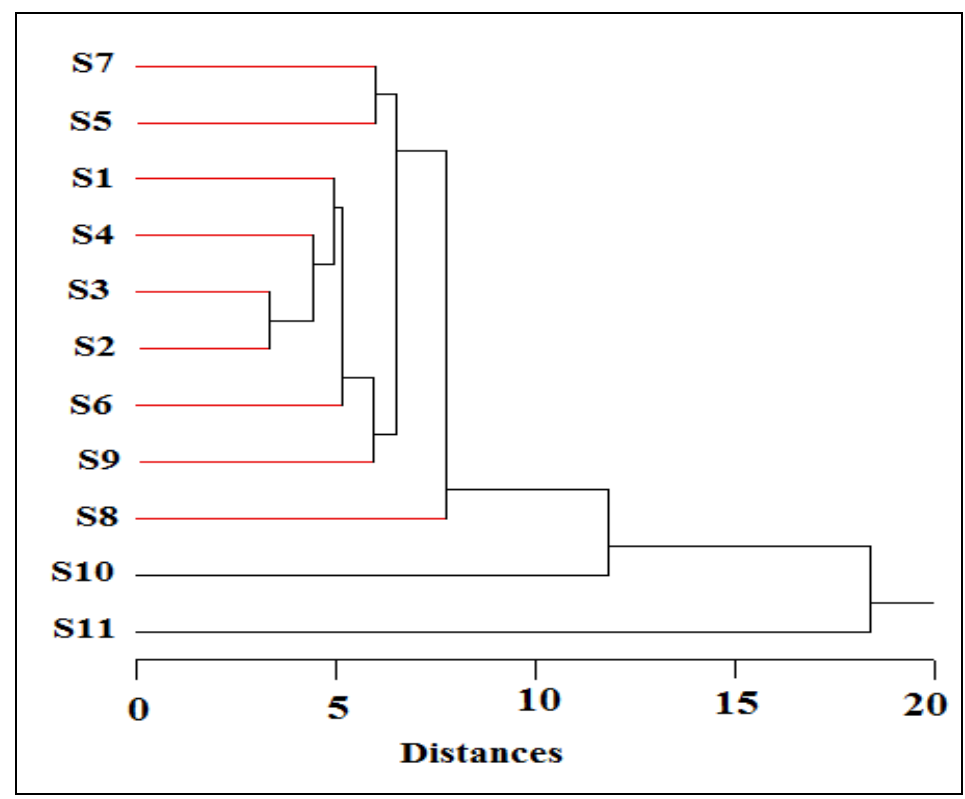

Figure 4: Dendrogram showing the affinity among the sampling stations S1-S11. The relative abundance of land snail species in each sampling station was used.

The linkage method is single linkage, and Euclidean distance.

\section{CONCLUSIONS}

Land snail communities from the Cisnădie River valley are shaped by their habitat. The forest areas have a rich land snail fauna with valuable elements including the endemic species Alinda viridana and Drobacia banatica, the only species from the Annex II of the Council Directive 92/43/EEC on the Conservation of natural habitats and of wild fauna and flora (Habitats Directive).

$D$. banatica was found in ten of the eleven sampling stations, and is more abundant in the upstream sector. As a result of degradation by human activities, the species diversity decreases and, in the proximity of human settlements the communities are based upon ubiquitous species such as Helix pomatia and Euomphalia strigella, or on those species that find favourable conditions for their particular requirements such as Vestia elata and Helix lutescens. These particular conditions may be very different between adjacent locations. As the pressure generated by human activities decreases, land snail communities are re-established, but their structure depends on the dimensions of habitat fragments, previous structure of the habitat and the potential connection with other natural habitats that can supply the species richness. In the case of the Cisnădie River, the sampling points located downstream have particular land snail communities, inhabiting natural habitat patches that are in contact with a remnant forest. Unfortunately the regularization works conducted along the river have separated the upstream land snail populations from those downstream. It is still possible that some individuals are transported downstream during floods, but it is less probable that they contribute substantially to the land snail community of this sector. Despite the high level of human disturbance, these habitat fragments are still able to preserve a high diversity and function as biodiversity reservoirs in a highly anthropic landscape, sheltering species with conservation value. The future of land snail species in this type of habitat largely depends on how these river valleys are managed. 


\section{REFERENCES}

1. Bank R. A., (ed.), 2013 - Mollusca, Gastropoda, Fauna Europaea version, 2.6.2, http://www.faunaeur.org/.

2. Dedov I. and Penev L., 2000 - Species composition and origins of the terrestrial gastropod fauna of Sofia City, Bulgaria, Ruthenica, 10, 2, 121-131.

3. Douglas D. D., Brown D. R. and Pederson N., 2013 - Land snail diversity can reflect degrees of anthropogenic disturbance, Ecosphere, 4, 2, 28, doi:10.1890/ES12-00361.1.

4. Gheoca V., 2012 - Considerations regarding land snails diversity in urban areas. Case study the city of Sibiu, Bruckenthal Acta Musei, VII, 3, 541-548.

5. Grossu A. V., 1981 - Gastropoda Romaniae 3, Ordo Stylommatophora, Suprafamiliile Clausiliacea şi Achatinacea, Edit. Litera, Bucureşti, 248. (in Romanian)

6. Grossu A. V., 1983 - Gastropoda Romaniae, 4, Ordo Stylommatophora, Suprafamiliile Arionacea, Zonitacea, Ariophantacea şi Helicacea, Edit. Litera, Bucureşti, 538. (in Romanian)

7. Grossu A. V., 1987 - Gastropoda Romaniae, 2, Subclasa Pulmonata, Ordo Basommatophora şi Ordo Stylommatophora, Suprafam. Succineacea, Cochlicopacea, Pupillacea, Edit. Litera, Bucureşti, 388. (in Romanian)

8. Horsák M., Juřičková L., Kintrová K. and Hájek O., 2009 - Patterns of land snail diversity over a gradient of habitat degradation: a comparison of three Czech cities, Biodiversity and conservation, 18, 13, 3453-3466.

9. Horsák M., Lososová Z., Čejka T., Juřičková L. and Chytrý M., 2013 - Diversity and biotic homogenization of urban land-snail faunas in relation to habitat types and macroclimate in 32 Central European Cities, PLoS ONE, 8, 8, e71783, doi:10.1371/journal.pone.0071783.

10. McKinney M. L., 2002 - Urbanization, Biodiversity, and Conservation. The impacts of urbanization on native species are poorly studied, but educating a highly urbanized human population about these impacts can greatly improve species conservation in all ecosystems, BioScience, 52, 10, 883-890.

11. McKinney M. L., 2008 - Effects of urbanization on species richness: a review of plants and animals, Urban ecosystems, 11, 161-176.

12. Pokryszko B. M. and Cameron R. A. D., 2005 - Geographical variation in the composition and richness of forest snail faunas in northern Europe, in Cameron R. A. D., Nekola J. C., Pokryszko B. M. and Wells F. E. (eds), Pattern and process in land mollusc diversity, Perth: Records of the Western Australian Museum, Supplement, 68, 115-132.

13. Stoll P., Oggier P. and Baur B., 2009 - Population dynamics of six land snail species in experimentally fragmented grassland, Journal of Animal Ecology, 78, 236-246.

14. Welter-Schultes F. W., 2012 - European non-marine molluscs, a guide for species identification, Planet Poster Editions, Göttingen, 1-674. 